\title{
Influence of land-use/land-cover change on landscape connectivity for an endemic threatened amphibian (Argenteohyla siemersi pederseni, Anura: Hylidae)
}

\author{
Facundo Schivo (1D) María Cruz Mateo-Sánchez • Valeria Bauni • \\ Rubén Darío Quintana
}

Received: 14 January 2020/Accepted: 13 May 2020

(C) Springer Nature B.V. 2020

\begin{abstract}
Context Modifications in natural landcover generally result in a loss of habitat availability for wildlife and it's persistence will depend largely on their spatial configuration and functional connections. Argenteohyla siemersi is a threatened and endemic amphibian whose habitat is composed of forest patches near rivers and water bodies edges.

Objectives This study aimed to analyse the accessible habitat for this species and identify key elements to maintain its ecological network in two different types
\end{abstract}

F. Schivo $(\varangle) \cdot$ R. D. Quintana

Instituto de Investigación e Ingeniería Ambiental (IIIA), CONICET-UNSAM, Campus Miguelete, 25 de Mayo y Francia (1650), San Martín, Provincia de Buenos Aires, Argentina

e-mail: fschivo@unsam.edu.ar

R. D. Quintana

e-mail: rquintana@unsam.edu.ar

M. C. Mateo-Sánchez

Ecología y Gestión Forestal Sostenible, E.T.S.I. Montes, Forestal y Medio Natural, Universidad Politécnica de Madrid, Madrid, Spain

e-mail:mc.mateo@upm.es

V. Bauni

Fundación de Historia Natural Félix de Azara -

Departamento de Ciencias Naturales y Antropológicas, CEBBAD - Universidad Maimónides, Hidalgo 775, Piso 7 (1405), Buenos Aires, Argentina

e-mail: valeria.bauni@fundacionazara.org.ar of land uses: an anthropized area with extensive cattle raising and a protected area.

Methods The structural and functional characteristics of both landscapes were analyzed. The connectivity at landscape level and the contribution of each habitat patch were evaluated through simulation models with different dispersion distances in the context of the graph theory.

Results In both landscapes, nine types of landcover were identified with different compositions. Remarkable differences were found in habitat connectivity for this amphibian species between both landscapes. As the percentage of dispersion distance increases, reachable habitat increases as well, although with higher percentages in the protected area. Two corridors were identified in the protected landscape and one in the rangeland one; patches and key links constituted all of them.

Conclusions The present work provides spatially explicit results with a quantitative basis. It could be useful as a tool for the development of management plans aimed at guaranteeing the functionality of the ecological network for this endangered species and, therefore, contribute to its long-term conservation.

Keywords Amphibian - Argentina - Connectivity · Conservation - Habitat loss - Landscape degradation . Mburucuyá National Park · Rangelands 


\section{Introduction}

The decrease in biodiversity is one of the main environmental problems worldwide (Hanski 2005). Habitat loss and degradation due to factors such as land-use changes and infrastructure development (Forman and Alexander 1998; Sala et al. 2000) have been identified among the main processes responsible for this phenomenon (Chapin III et al. 2000).

Modifying landscape configuration can compromise its structural and functional integrity (With 1997; Begon et al. 1999). The diversity, extent, distribution and shape of the landscape elements have an influence on a variety of critical ecological processes necessary for the persistence of populations (Wiens et al. 1993; Fraterrigo et al. 2009).

Landscape fragmentation process (Begon et al. 1999) is one of the most frequent alterations because of anthropogenic activities. Its adverse effects on wildlife populations are diverse depending on the perception of the species on the landscape. For habitat specialist species, landscape fragmentation could imply a new configuration with an inappropriate composition or distribution of elements used by them for feeding, reproduction or shelter, resulting in an increase in reproductive isolation (Opdam et al. 1993; Forman 1995). From a functional approach, landcover changes associated with the fragmentation process involve landscape connectivity variations, an attribute that measures the ecological flows through the territory (Taylor et al. 1993; Bodin and Saura 2010).

Connectivity determines the effective and attainable habitat area within a territory for a given species (Saura and Pascual-Hortal 2007). Maintaining and improving landscape connectivity is today considered a key part of efforts to protect biodiversity (Crooks and Sanjayan 2006). Facilitates the capacity movement to satisfy ecological requirements, reduces populations isolation and can counteract the potentially adverse effects of fragmentation by favouring genetic flow (Taylor et al. 1993; Minor and Urban 2008).

In this context, amphibians are a sensitive group because they respond to changes in environmental conditions in both aquatic and terrestrial ecosystems (Blaustein and Wake 1990; Stebbins and Cohen 1995; Cushman 2006; Becker et al. 2007; Rustigian et al. 2007). Degradation, fragmentation, or changes in the extent and habitat connectivity within landscape can produce substantial changes in the presence, distribution and dispersion of individuals in this group (Corn and Fogleman 1984; Fahrig et al. 1995; Joly et al. 2001, 2003; Fahrig 2007). This is the case of Argenteohyla siemersi (red-spotted argentina frog, Mertens 1937) that inhabits forests associated with wetlands in Argentina, Paraguay and Uruguay and constitutes a single specie within this genus with two allopatric subspecies: A. s. siemersi and A. s. pederseni (Cajade et al. 2010, 2017). These environments are currently being degraded or destroyed by productive activities, mainly extensive cattle raising and afforestation (Lavilla et al. 2004). For this reason, this species has been listed as "endangered" by the International Union for the Conservation of Nature (IUCN 2019). Considering this situation and the lack of information on this species that allows establishing actions for its conservation, the objective of the present work is to evaluate landscape structural and functional connectivity due to anthropic use for this frog in a rangeland landscape compared to the natural condition represented in a protected area. In addition, it is attempted to identify those key fragments that contribute to the preservation of this species in the studied area.

\section{Methods}

\section{Focal species}

The study focuses on the subspecies A. s. pederseni, endemic to northeastern Argentina with a restricted distribution to a few locations (William and Bosso 1994; Fig. 1). It presents a typical two-phase life cycle (Grosse and Nöllert 1993). The adult stage have a size snout-vent 70-75 mm length, and a body mass of 19-25 g, and inhabits in the bromeliads present in forests (Álvarez et al. 2002; Cajade et al. 2013) and the emergent vegetation at the edges of semi-permanent ponds constitutes its habitat in the reproductive period (Cajade et al. 2010). Most of published works on this species are about its systematic (William and Bosso 1994; Céspedez 2000; Cajade et al. 2013; Pineiro et al. 2019), and a few describes their reproductive ecology (Diminich and Zaracho 2008; Cajade et al. 2010), songs (Zaracho and Arieta 2008) and anti-predatory defence mechanisms (Cajade et al. 2017). Little is known about habitat requirements of this species (Cajade et al. 2013). In addition, few information 


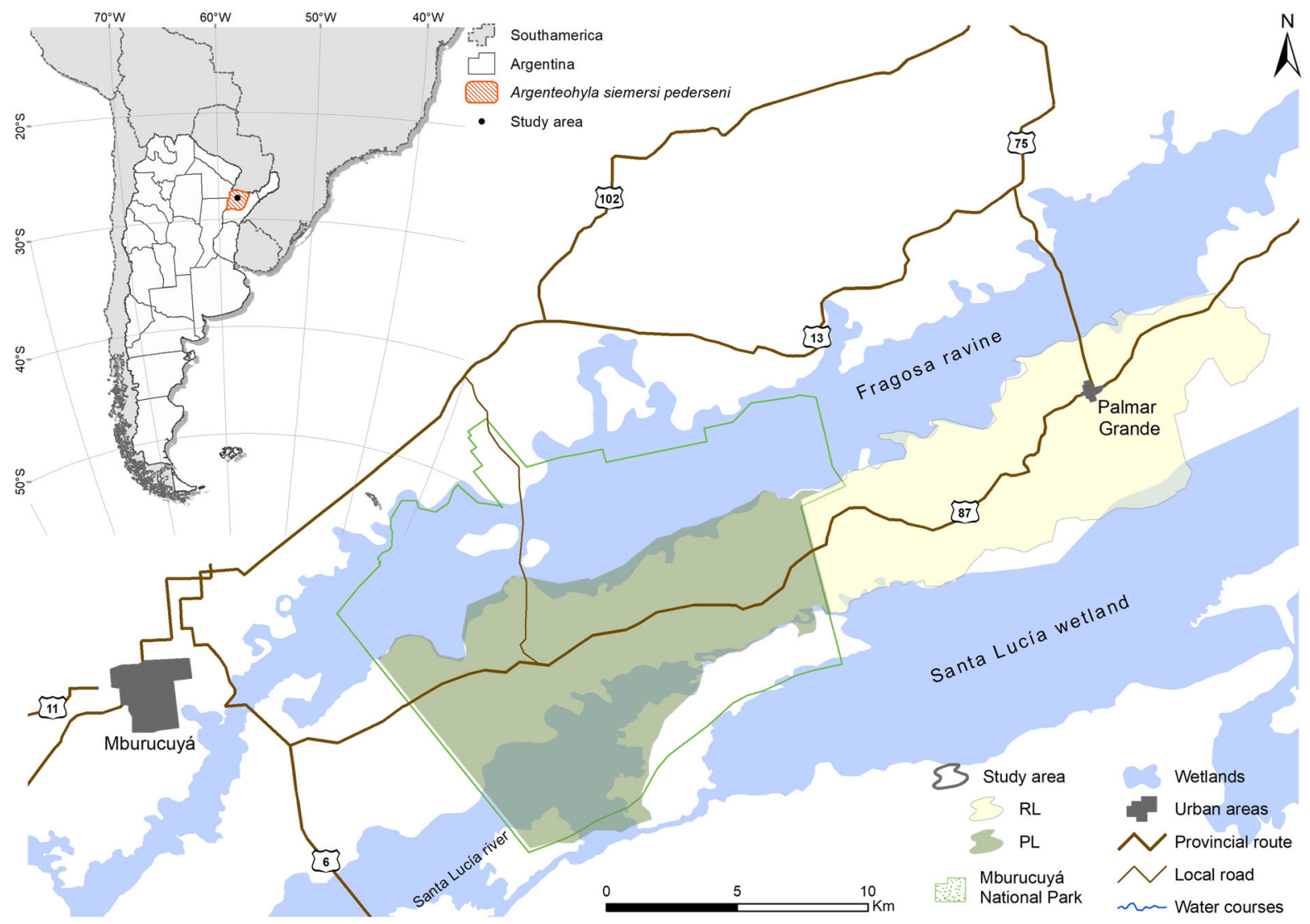

Fig. 1 Geographic distribution of Argenteohyla siemersi pederseni (adapted from the IUCN species distribution maps) in northeastern Argentina. Detail of the location of the study

about dispersion distance of Neotropical amphibians is available (Alex Smith and Green 2005).

Study area

The study area is located in northeast of Argentina, on a sandy belt developed by fluvial depositions of the Paraná river during the Pliocene (Brea and Zucol 2011) limited by the Fragosa ravine to the north and the Santa Lucía wetlands to the south. On these belts are located numerous circular ponds originated by wind erosion and by pseudo-karstic dissolution or dragging processes (Popolizio 1996; Contreras 2011) along with hydrophilic and sub-xerophilous forests that reach a $21 \%$ of the surface coverage. Herbaceous are the most extensive communities, covering $79 \%$ of the area. Among them stand out grasslands of $0.5 \mathrm{~m}$ of average height, dominated by Andropogon lateralis or Elyonurus muticus, sometimes interspersed with palm area in the Corrientes Province. It includes the protected (PL) and the rangeland (RL) landscapes

groves of Butia yatay or Copernicia australis and freshwater or floating marshes (Saibene and Montanelli 1997; Arbo 2004).

The climate in this region is humid subtropical, $\mathrm{Cfa}$ under the Köppen climate classification, with mean annual temperature between 21 and $23{ }^{\circ} \mathrm{C}$ for the 1961-1990 period, low annual thermal amplitude and an average annual rainfall of $1300 \mathrm{~mm}$ (Meza-Torres et al. 2013).

Extensive cattle raising is one of the main activities developed on this area (Forclaz 2001). Mburucuyá National Park $\left(27^{\circ} 58^{\prime}-26^{\circ} 05^{\prime} \mathrm{S}, 57^{\circ} 59^{\prime}-58^{\circ} 08^{\prime} \mathrm{W}\right)$ was established to preserve 17,086 ha of natural landscape previously to the intense productive transformation of the area. The park is crossed by the Provincial Route 87 (PR87), which connects the towns of Mburucuyá and Palmar Grande. Among the specific conservation objectives of this protected area, the protection of the A. s. pederseni is found (APN 2002). 
For the present study we consider 9787.4 ha of Mburucuyá National Park as the protected landscape (PL) and the 8394.8 ha of a rangeland landscape (RL) that extends from the east of the PL to the town of Palmar Grande (Fig. 1).

\section{Landcover characterization}

\section{Structural landcover configuration}

The landscape structure was characterized using a classification based on a multitemporal-stack of Landsat 8 Path/Row 226/79 Tier_1 optical satellite images (visible, NIR and SWIR bands with spatial resolution of $30 \times 30 \mathrm{~m}$ ), acquired from the U.S. Geological Survey (USGS, https://earthexplorer.usgs. gov/). Representative images of the rainy season $(2017 / 04 / 22)$ and the dry season (2018/01/03) were selected to improve the discrimination of coverage associated with water pulses. The classification was performed using the unsupervised algorithm Iterative Self-Organizing Data Analysis Techniques (ISODATA) with the ENVI program. Subsequently, and for operational purposes, a cluster analysis of their spectral signatures was performed in order to reduce the number of classes using the average Euclidean distance. The typology of landscape elements was defined based on field surveys data (Schivo 2015). Roads and houses were digitized from satellite images of higher spatial resolution (Google Earth, https:// earth.google.com).

To characterize the structural configuration of both landscapes, eight descriptive metrics (McGarigal and Marks 1995; Table 1) were calculated using V-Late extension (Lang and Tiede 2003) for ArcGis 10.x (ESRI 2011).

\section{Habitat types}

Landcover used as habitat for this amphibian species was identified. The forest-associated class, described as permanent habitat (Álvarez et al. 2002; Cajade et al. 2013) and the edges of water bodies used as a reproductive and tadpole development habitat (Cajade et al. 2010) were defined as nodes. For this model, it was assumed that all the patches with the characteristics described by these authors constituted the potential habitat for this frog. This was assumed due to the difficulty of sampling all the patches available in a large area to corroborate the presence of species on a huge spatial scale or when they are small and cryptic as has been pointed out in other studies (Rubio et al. 2012; Schivo et al. 2015).

On the other hand, links are the elements that connect pairs of nodes and represent a possible way of direct dispersion between habitat fragments through the landscape (Saura and Rubio 2010).

\section{Landcover friction}

Each habitat type was assigned to a resistance coefficient (with values from 1 to 1000) based on habitat requirements and ecological costs (Table 2). The lowest cost was attributed to the habitat of adult individuals (forested areas; Fo) and breeding sites (water bodies edges; WBE), since they are the usual habitats of the A. s. pederseni. Other coverages such as open areas or low herbaceous plants cover, which increases the probability of desiccation or predation, increase the friction value. Similarly, open water habitats increase the friction value as well. The fact that this frog is not a good swimmer and that this habitat type exposes it to predators is that this environment does not good enough for its dispersion. for each landcover class for the structural landscape
Table 1 Calculated metrics characterization

\footnotetext{
${ }^{\mathrm{a}}$ Values near 1 indicate simple circular perimeters and values near 2 indicate complex edge shapes
}

\begin{tabular}{llll}
\hline Metric & & Unit & Description \\
\hline Density & NumP & - & Number of patches \\
& \%DNumP & $1 / 100$ ha & Patch density \\
Area & CA & Ha & Total class area \\
& MPS & Ha & Mean patch size \\
& PSSD & Ha & Patch size standard deviation \\
Edge & TE & Km & Total edge \\
& MPE & Km & Mean patch edge \\
Complexity & MFRACT & $1 / \mathrm{m}$ & Mean patch fractal dimension \\
\hline
\end{tabular}


Table 2 Habitat quality (DPH) and resistance coefficient (FRC) of each landcover type: Water bodies edge (WBE) and forest $(\mathrm{Fo})$ habitat, bulrushes $(\mathrm{Br})$, sedges $(\mathrm{Sd})$, grassland $(\mathrm{Gs})$, grazed grasslands and bare soil (GG-BS), water bodies (WB), and infrastructure (houses and roads). Values adapted from Joly et al. (2003)

\begin{tabular}{lll}
\hline Landcover & DPH & FRC \\
\hline WBE & 100 & 1 \\
Fo & 100 & 1 \\
$\mathrm{Br}$ & 75 & 5 \\
$\mathrm{Sd}$ & 50 & 5 \\
Gs & 25 & 50 \\
GG-BS & 0 & 50 \\
WB & 0 & 80 \\
Houses & 0 & 1000 \\
Roads & 0 & 1000 \\
\hline
\end{tabular}

Finally, the higher costs were attributed to dispersal barriers such as houses and roads (Ray et al. 2002; Joly et al. 2003).

\section{Connectivity}

Landscape connectivity was evaluated based on graph theory (Urban and Keitt 2001) using Conefor 2.6 software (Saura and Torné 2009), considering as attribute the area of each node. Links were defined as the least-cost path (LCP) and were attributed with the length of the LCP. This was calculated as the minimum distance between each pair of nodes weighted by friction (Wiens 2001; Adriaensen et al. 2003) using the Linkage Mapper software (McRae and Kavanagh 2011). The least cost modelling is considered the most efficient approach applied to amphibians' dispersion analysis even more so when the dispersal mechanisms remain unknown (Joly et al. 2003; Decout et al. 2012).

Both, the global connectivity of the ecological network and the availability of habitat (PC) were estimated using a probabilistic model in which the habitat area of each node, the LCP and the dispersal capacity of the species are the inputs. For global connectivity, the variation of the percentage of reachable area (Equivalent Connected Area, ECA), was evaluated (Saura et al. 2011). Direct dispersion probability between pairs of patches $\left(\mathrm{p}_{\mathrm{ij}}\right)$ was calculated from a decreasing exponential function (Eq. 1,
Saura and Pascual-Hortal 2007). This function was modelled from a known dispersion distance $\left(\mathrm{d}_{\mathrm{ij}}\right)$ and its probability (e.g., the median dispersal distance has a probability of 0.5 , while for the maximum dispersal distance the probability drops to 0.01 ; Saura and Torné 2009). As there is no information about dispersal capacity for this species, connectivity was simulated for 12 distances between 25 and $1000 \mathrm{~m}$ depending on the different maximum dispersion distances for other species of hylids (Alex Smith and Green 2005). This range of distances contemplates those most frequent events of short distance dispersion as colonization events of occupation of distant areas.

$p_{i j}=e^{-k * d_{i j}}$

where $p_{i j}$ is the probability of direct dispersion between patches $i$ and $j, k k$ is a constant that is adjusted from a known distance and probability value, and $d_{i j} d i j$ is the distance between patches $i$ and $j$.

The importance of each element was evaluated for each distance analyzed as the variation of connectivity $(d P C)$ if that element was removed. For this, the $d P C_{k}$ value (probability of connectivity of the patch $k k$ ) and its three complementary fractions were calculated: intrapatch connectivity $\left(\right.$ dPCintra $\left._{k}\right)$, direct dispersion flow probability $\left(d P C f l u x_{k}\right)$ and contribution of the patch $k k$ to the connectivity between the rest of the network (dPCconnector ${ }_{k}$ ) (Eq. 2, Saura and PascualHortal 2007; Saura and Torné 2009).

$$
\begin{aligned}
d P C_{k} & =d P C_{\text {intrak }}+d P C_{\text {flux } k}+d P C_{\text {connectork }} \\
& =100 * \frac{P C-P C_{\text {remove }}}{P C}
\end{aligned}
$$

where $P C=\sum_{i=j}^{n} \sum_{i=j}^{n} a_{i} * a_{j} * p_{i j}^{*}$, with $a_{i} a_{i}$ and $a_{j} a_{j}$ attribute values of patch $i$ and $j$, and $p_{i j} * p_{i j}^{*}$ the probability that patches $i$ and $j$ are connected.

$d P$ Cintra $_{k}$ (Eq. 3) is the available habitat provided by the patch $k$ itself through the area it contains, regardless of its position in the landscape.

$d P C_{\text {intra }}=a_{i} * a_{j}$, when $i=j=k\left(a_{k}^{2}\right)$

$d P C f l u x_{k}$ (Eq. 4) is the direct dispersion flow through the patch connections with the rest of the network when it is the point of origin or destination of that flow. This component depends both on the area of patch $k k$ and on its position in the landscape. 
$d P C_{f l u x}=a_{i} * a_{j} * p_{i j} *$, when $i=k$ or $j=k$ and $i \neq j$

dPCconnector $_{k}$ (Eq. 5) is the contribution of patch $k k$ to the connectivity between the rest of the network, as a connector element, only if it is part of an optimal or shortest path between two other patches $i$ and $j$. This component is independent of the patch area $k$ and depends only on their topological position in the landscape network (Saura and Pascual-Hortal 2007; Saura and Torné 2009; Saura and Rubio 2010).

$d P C_{\text {connector }}=a_{i} * a_{j} * p_{i j} *$, when $i \neq k, j \neq k$

Priority patches for maintaining connectivity were identified as those whose $d P C$ value was within the 90th percentile for all dispersion distances evaluated. Similarly, the most important patches were also identified as connector elements from the $\mathrm{APC}$ connector fraction and the links. These were evaluated from the variation of the $d P C$ if that connector is removed.

\section{Results}

Structural landscape analysis

Nine landcover types were identified: water bodies edges (WBE), forest (Fo), wetlands (bulrushes -Brand sedges -Sd-), grassland (Gs), grazed grasslands and bare soil (SG-BS), water bodies (WB), and infrastructure (houses and roads) (Fig. 2).

The dominant coverages in the studied landscapes were wetlands (WBE, $\mathrm{Br}$ and $\mathrm{Sd}$ ) and grassland (Gs and SG-BS), which is reflected in the results obtained from the metrics considered. These coverages were the most abundant, both in area and in number and density of patches. However, both landscapes showed structural differences between them. In the rangeland landscape there was a greater area covered by grazed grasslands and bare soil with respect to the protected landscape. Vegetated water bodies edges were also more abundant in this landscape. On the contrary, there was a larger total area and a mean patch size of forest in the National Park because of the management and conservation plans. Although the amount of forest fragments in the rangeland landscape was similar to the protected area, the average patch size was smaller. As for water bodies (WB) their area was similar in both landscapes (Table 3 ). In addition, 38 nodes (20 Fo and $18 \mathrm{WBE}$ ) were identified in the protected landscape with a key function as connecting elements. Twenty-seven of them (71\%) are also critical for maintaining connectivity, reinforcing their importance. Analyzing their spatial distribution along with the 55 priority links identified, two corridors were recognized. These corridors were, composed of a series of permanent and temporary habitat patches, which were linearly concatenated and related with priority nodes, which were functioning as steppingstone corridors (Fig. 4b). On the other hand, in the rangeland landscape, 45 nodes (20 Fo and $25 \mathrm{WBE}$ ) were identified as key connecting elements of which seven $(15.5 \%)$ were also classified as priority nodes for their contribution to landscape connectivity. In turn, 71 links showed a key role in maintaining connectivity in this landscape. In this case, a single corridor was identified (Fig. 4b).

Finally, three critical areas were identified as barriers within the protected landscape, where both corridors intersect the PR87 (Fig. 4b). These areas are critical because amphibians are exposed to road-kill risk and the lack of vegetation cover increases exposure to predators and desiccation hazard.

Functional landscape analysis

Functional differences between both landscapes were found. In them, as dispersion distance increases, the percentage of habitat achievable also increases. For each of the distances considered, this percentage was always higher in the protected landscape (Fig. 3).

For the shorter dispersion distance, the greatest contribution to connectivity was associated with habitat availability within the fragment (intra-patch connectivity, dPCintra component). In particular, and for the shortest distances, this contribution was always greater in the rangeland landscape (Fig. 3) along with a lower percentage of reachable habitat (Fig. 3).

As the dispersion distance increases, a decrease in the participation of dPCintra component and an increase in the contribution of interparches components (dPCflux y dPCconnector; Fig. 3) was observed in both landscapes. In the protected landscape, at the major dispersion distances considered, the $d P C f l u x$ was greater than the $d P C$ connector while in the rangeland landscape this relationship was reversed 


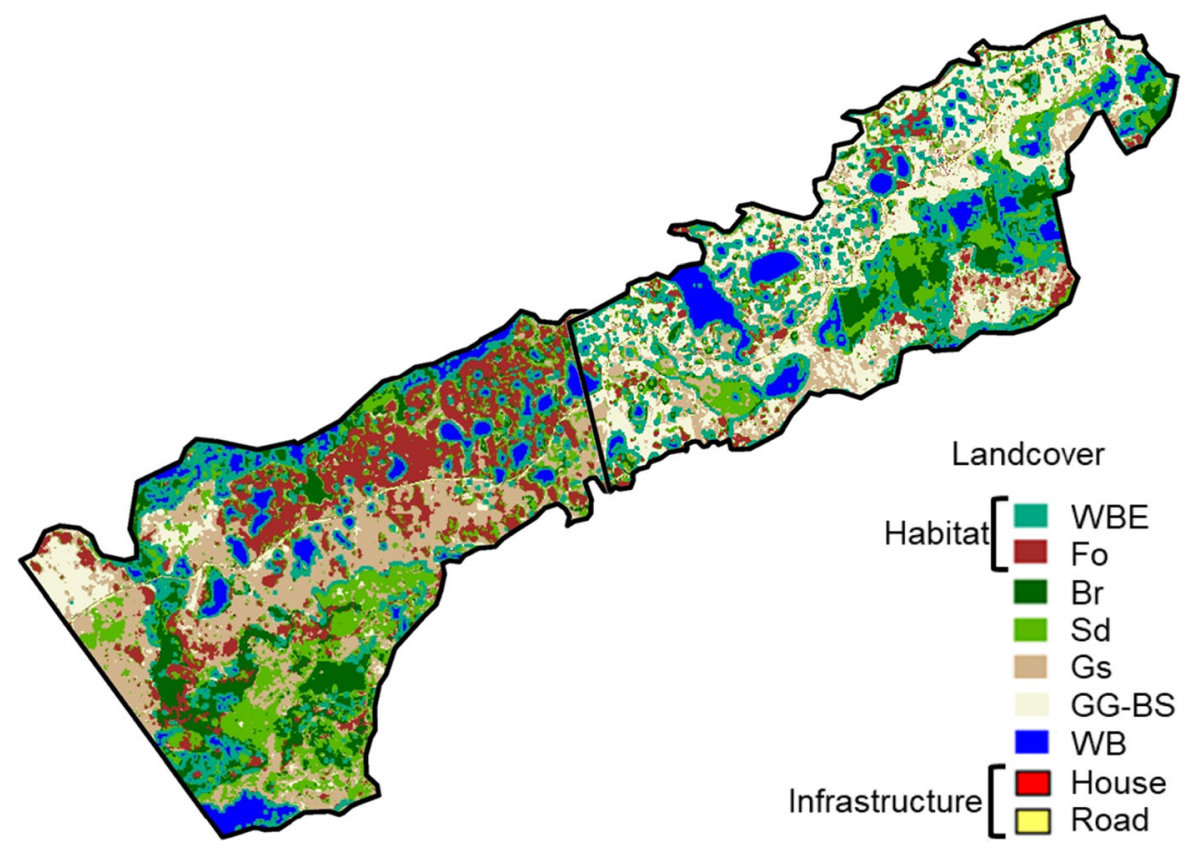

Fig. 2 Landcover map classification of a sector of the studied area, Corrientes Province, Argentina: water bodies edge (WBE) and forest $(\mathrm{Fo})$ habitat, bulrushes $(\mathrm{Br})$, sedges $(\mathrm{Sd})$, grassland

(Fig. 3). In the protected area, the percentage of reachable habitat was always greater.

As for the most important nodes in the contribution to the protected landscape connectivity, 23 (3\%) forest fragments grouped 1743.7 ha $(96.3 \%)$ and $24(9 \%)$ fragments of water bodies edges add up to 694.3 ha $(41.8 \%)$ of this habitat type. On the contrary, in the rangeland landscape, only 15 nodes from the 54 priority sites identified corresponded to forest (2\% of the Fo fragments), which add up to 123.3 ha (30.6\%) of the total habitat area for adults of this species. The remaining 39 nodes ( 1457.3 ha; $65.7 \%$ ) correspond to water bodies edges and represent $92.2 \%$ of the area, with the greatest contribution to landscape connectivity within this landscape (Table 4; Fig. 4a).

In addition, 38 nodes ( 20 Fo and $18 \mathrm{WBE}$ ) were identified in the protected landscape with a key function as connecting elements. Twenty-seven of them $(71 \%)$ are also critical for maintaining connectivity, reinforcing their importance. Analyzing their spatial distribution along with the 55 priority links identified, two corridors were recognized. These corridors were, composed of a series of permanent and temporary habitat patches, which were linearly concatenated and related with priority nodes, which
(Gs), grazed grasslands and bare soil (GG-BS), water bodies (WB), and infrastructure (houses and roads)

were functioning as stepping-stone corridors (Fig. 4b). On the other hand, in the rangeland landscape, 45 nodes ( 20 Fo and $25 \mathrm{WBE}$ ) were identified as key connecting elements of which seven $(15.5 \%)$ were also classified as priority nodes for their contribution to landscape connectivity. In turn, 71 links showed a key role in maintaining connectivity in this landscape. In this case, a single corridor was identified (Fig. 4b).

Finally, three critical areas were identified as barriers within the protected landscape, where both corridors intersect the PR87 (Fig. 4b). These areas are critical because amphibians are exposed to road-kill risk and the lack of vegetation cover increases exposure to predators and desiccation hazard. In addition, 38 nodes (20 Fo and 18 WBE) were identified in the protected landscape with a key function as connecting elements. Twenty-seven of them $(71 \%)$ are also critical for maintaining connectivity, reinforcing their importance. Analyzing their spatial distribution along with the 55 priority links identified, two corridors were recognized. These corridors were, composed of a series of permanent and temporary habitat patches, which were linearly concatenated and related with priority nodes, which were functioning as stepping-stone corridors 
Table 3 Structural landscape characteristics of both studied landscapes

\begin{tabular}{|c|c|c|c|c|c|c|c|c|c|}
\hline \multirow[t]{2}{*}{ Landscape type } & \multirow[t]{2}{*}{ NumP } & \multirow{2}{*}{$\begin{array}{l}\text { \%DNumP } \\
\text { (1/100 ha) }\end{array}$} & \multicolumn{2}{|l|}{$\mathrm{CA}$} & \multirow{2}{*}{$\begin{array}{l}\text { MPS } \\
\text { (ha) }\end{array}$} & \multirow{2}{*}{$\begin{array}{l}\text { PSSD } \\
\text { (ha) }\end{array}$} & \multirow{2}{*}{$\begin{array}{l}\text { TE } \\
(\mathrm{km})\end{array}$} & \multirow{2}{*}{$\begin{array}{l}\text { MPE } \\
(\mathrm{km})\end{array}$} & \multirow[t]{2}{*}{ MFRACT } \\
\hline & & & (ha) & $(\%)$ & & & & & \\
\hline \multicolumn{10}{|l|}{ Protected } \\
\hline WBE & 268 & 2.7 & 1661.4 & 17.0 & 6.2 & 20.0 & 457.3 & 1.71 & 1.33 \\
\hline Fo & 718 & 7.3 & 1810.6 & 18.5 & 2.5 & 21.2 & 494.6 & 0.69 & 1.42 \\
\hline $\mathrm{Br}$ & 607 & 6.2 & 1005.7 & 10.3 & 1.7 & 9.6 & 314.5 & 0.52 & 1.41 \\
\hline $\mathrm{Sd}$ & 2118 & 21.6 & 1816.5 & 18.6 & 0.9 & 6.6 & 787.6 & 0.37 & 1.40 \\
\hline Gs & 1254 & 12.8 & 2380.5 & 24.3 & 1.9 & 25.3 & 662.4 & 0.53 & 1.40 \\
\hline GG-BS & 724 & 7.4 & 501.8 & 5.1 & 0.7 & 7.7 & 201.2 & 0.28 & 1.41 \\
\hline WB & 161 & 1.6 & 550.2 & 5.6 & 3.4 & 11.0 & 120.9 & 0.75 & 1.37 \\
\hline Houses & 5 & 0.1 & 0.5 & 0.0 & 0.1 & 0.0 & 0.6 & 0.12 & 1.41 \\
\hline Roads & 9 & 0.1 & 60.3 & 0.6 & 6.7 & 8.8 & 40.6 & 4.52 & 1.48 \\
\hline \multicolumn{10}{|l|}{ Rangeland } \\
\hline WBE & 389 & 4.6 & 2217.2 & 26.4 & 5.7 & 17.7 & 581.8 & 1.50 & 1.34 \\
\hline Fo & 668 & 8.0 & 403.3 & 4.8 & 0.6 & 1.8 & 197.1 & 0.30 & 1.40 \\
\hline $\mathrm{Br}$ & 547 & 6.5 & 602.5 & 7.2 & 1.1 & 5.5 & 207.2 & 0.38 & 1.43 \\
\hline $\mathrm{Sd}$ & 2116 & 25.2 & 1074.5 & 12.8 & 0.5 & 2.7 & 568.7 & 0.27 & 1.41 \\
\hline Gs & 1715 & 20.4 & 1046.2 & 12.5 & 0.6 & 2.8 & 538.0 & 0.31 & 1.40 \\
\hline GG-BS & 889 & 10.6 & 2362.7 & 28.1 & 2.7 & 15.7 & 713.2 & 0.80 & 1.40 \\
\hline WB & 135 & 1.6 & 573.2 & 6.8 & 4.2 & 16.1 & 100.5 & 0.74 & 1.37 \\
\hline Houses & 181 & 2.2 & 17.0 & 0.2 & 0.1 & 0.0 & 22.2 & 0.12 & 1.41 \\
\hline Roads & 24 & 0.3 & 98.2 & 1.2 & 4.1 & 7.4 & 66.6 & 2.78 & 1.45 \\
\hline
\end{tabular}

WBE water bodies edge, $F o$ forest habitat, $B r$ bulrushes, $S d$ sedges, $G s$ grassland, $G G-B S$ grazed grasslands and bare soil, $W B$ water bodies, Ho houses, Ro roads

(Fig. 4b). On the other hand, in the rangeland landscape, 45 nodes (20 Fo and $25 \mathrm{WBE}$ ) were identified as key connecting elements of which seven $(15.5 \%)$ were also classified as priority nodes for their contribution to landscape connectivity. In turn, 71 links showed a key role in maintaining connectivity in this landscape. In this case, a single corridor was identified (Fig. 4b).

Finally, three critical areas were identified as barriers within the protected landscape, where both corridors intersect the PR87 (Fig. 4b). These areas are critical because amphibians are exposed to road-kill risk and the lack of vegetation cover increases exposure to predators and desiccation hazard.

\section{Discussion}

The results achieved in our work showed that anthropogenic intervention configured a deeply modified landscape with respect to the natural condition. The structural and functional configuration of the rangeland landscape generated a decrease in connectivity for Argenteohyla siemersi pederseni. Therefore, there is a lower availability of reachable habitat, which could affect the genetic exchange, and the flow of individuals. This fact could lead to local extinction of isolated populations of this frog (Hanski and Gilpin 1991; Kindlmann and Burel 2008). In this context, the expansion or intensification of cattle raising could have a negative impact on the conservation of the species, which has, at present, a jeopardized conservation status due to habitat loss and degradation (IUCN 2019).

Landscape configuration and connectivity

As Lambin et al. (2001) suggest, the land-cover and land-use changes is one of the biggest drivers of deforestation as well as of wetland loss and degradation (Gardner et al. 2015). In this study, when 


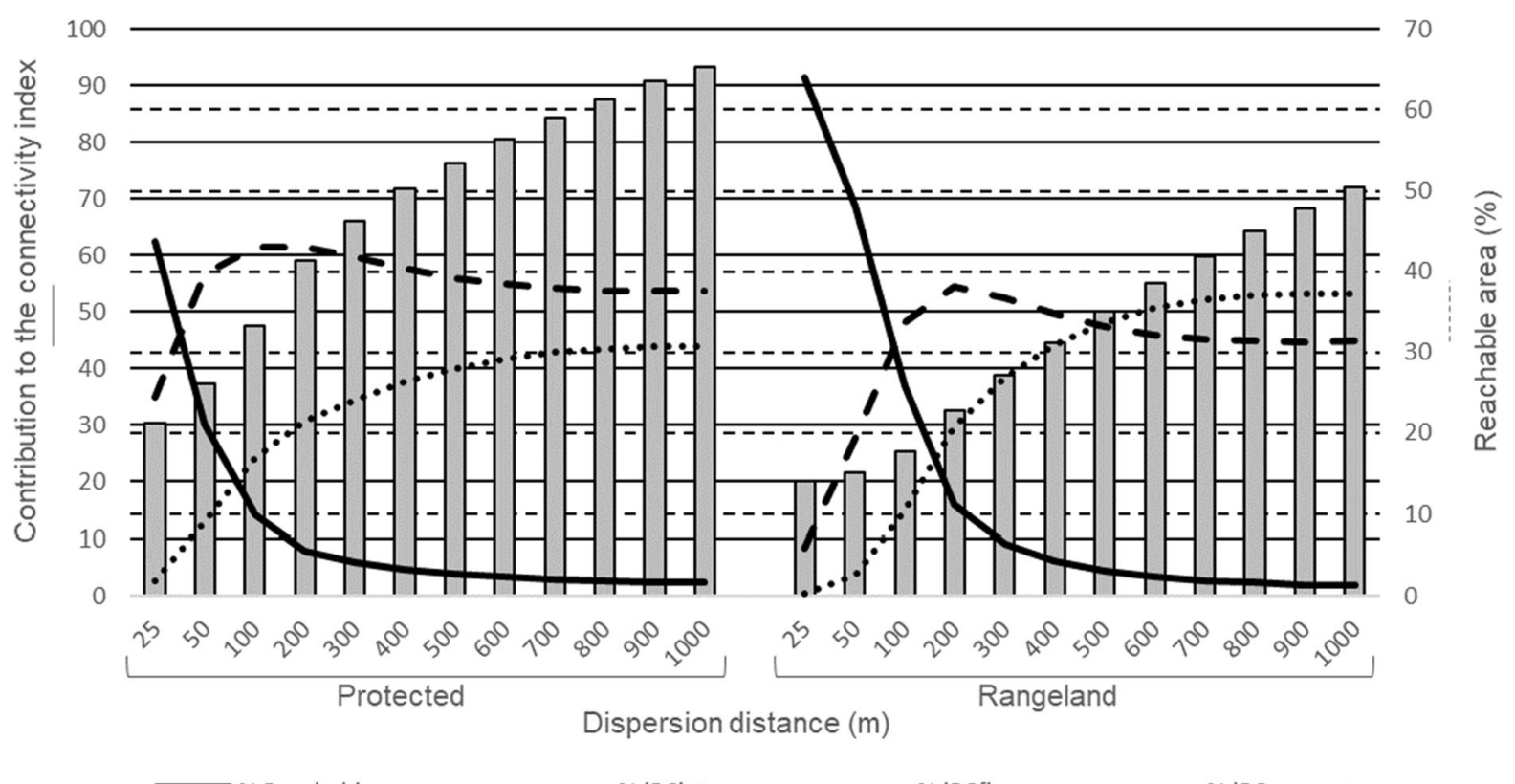

Fig. 3 Reachable area (bars) and contribution of dPCintra (continuous line), dPCflux (dashed line) and dPCconnector (dotted line) components to the connectivity index as a function of the twelve-dispersion distance considered for each landscape

Table 4 Contribution to the connectivity index dPC of those nodes included in the 90th percentile for both considered landscapes

\begin{tabular}{|c|c|c|c|c|c|c|}
\hline \multirow[t]{2}{*}{ Landscape } & \multirow[t]{2}{*}{ Landcover class } & \multicolumn{2}{|l|}{ Total class } & \multirow[t]{2}{*}{ Nodes } & \multicolumn{2}{|c|}{ Priority nodes } \\
\hline & & Area (ha) & $\operatorname{Ratio}^{\mathrm{a}}(\%)$ & & Area (ha) & $\operatorname{Ratio}^{\mathrm{b}}(\%)$ \\
\hline \multirow[t]{2}{*}{ Protected } & Fo & 1810.6 & 58.1 & 17 & 1052.1 & 60.2 \\
\hline & BS & 1661.4 & 41.8 & 14 & 694.3 & 39.8 \\
\hline \multirow[t]{2}{*}{ Rangeland } & Fo & 403.3 & 10.1 & 3 & 40.8 & 3.3 \\
\hline & BS & 2217.2 & 53.2 & 23 & 1180.5 & 96.7 \\
\hline
\end{tabular}

${ }^{\mathrm{a}}$ Considering the total class area for each landscape type

${ }^{\mathrm{b}}$ Considering the total priority area (Fo + WBE) for each landscape type

comparing both rangeland and protected landscapes, structural differences were observed in which the decrease of the forest cover stands together with an increase of the grazed grasslands and bare soil area. The change in landscape composition had direct impacts on amphibians' population dynamics (Cushman 2006). For instance, adult habitat loss has deep implications for its dispersion because of the increase of both the risk of predation and the probability of desiccation due to having to cross open areas (Mazerolle and Desrochers 2005). This results in an increase in friction that leads to fragmentation of populations by isolation (Fisher and Lindenmayer 2007).
Therefore, this process is critical for the maintenance of endangered species populations (Kerr and Deguise 2004), as we observed when comparing the extension of reachable habitat and the contribution of both intra and interpatch connectivity fractions.

On the other hand, rangeland landscape presented a greater coverage of vegetated border of ponds, the habitat of reproduction and development of larval stages. This may be related with the nutrients supply due to resuspension of sediments because of cattle trampling (Sahuquillo et al. 2012). In addition, resuspension of sediment also increases the abundance of periphyton (Middleton 2010), which could be food 
Fig. 4 a Nodes contribution to landscape connectivity network. dPCintra (a1), dPCflux (a2) and dPCconnector (a3) nodes contribution. b. Priority habitat nodes (Fo and WBE) and links in the studied landscapes. Gray boxes (b1) indicate a potentially critical area due to the increased risk of mortality because of the intersection between the provincial road and the identified corridors
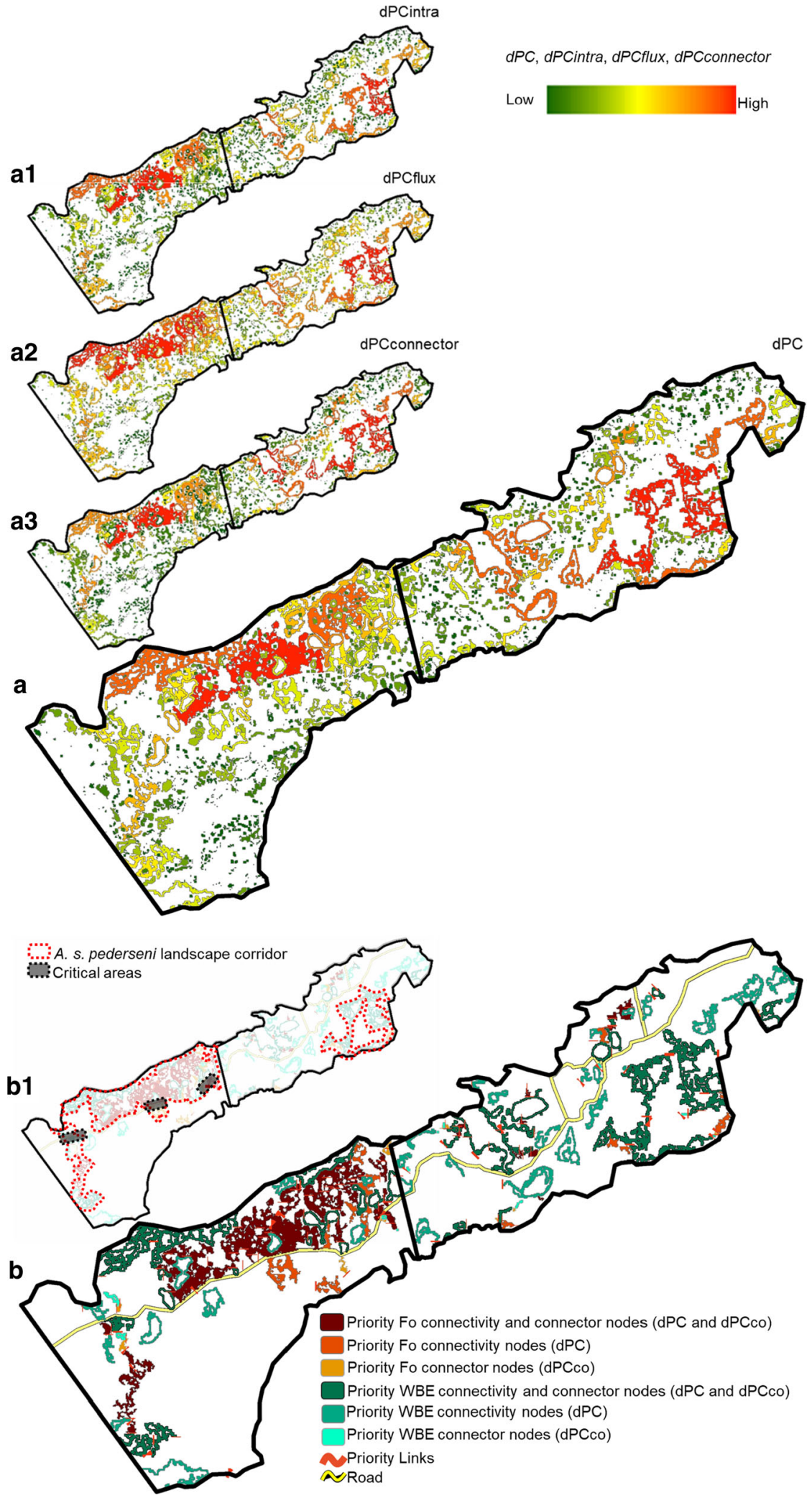
for larvae (Pollo et al. 2015). However, the increase in the area of this habitat type does not compensate in terms of connectivity the low representation of forests in this landscape. Consequently, the total habitat area in terms of intrapatch component was smaller than that found in the protected landscape.

\section{Contribution of landscape elements to connectivity}

At landscape scale, functional connectivity is much more complex than structural one (Mühlner et al. 2010) since it considers behavioural aspects such as the ability to move and disperse of each species along with spatial mosaic composition and configuration (Boitani et al. 2007). The modifications observed in the rangeland landscape due to land-cover and landuse changes results in a decrease in connectivity for each of the distances considered compared to the protected landscape. In particular, the relative contribution of each of the three components of connectivity reaches relatively constant levels after $600 \mathrm{~m}$. Therefore, the perception of connectivity for both landscapes is not modified from that distance threshold for this studied species.

For the shortest dispersion distances, which are the most frequent for hylids (Alex Smith and Green 2005), the degree of fragmentation in the rangeland landscape implies a small area of connected habitat (14\%). For the same distance, in the protected landscape, $21 \%$ of the total available habitat is connected. In the rangeland landscape, the greater contribution to connectivity provided by the $A P C$ intra component together with a lower percentage of reachable habitat suggests greater functional fragmentation as a consequence of cattle impact. The decrease in the contribution of this component together with an increase in the flow contribution (dPCflux) and the landscape integral connectivity of the connector component (dPCconnector) due to the increase in the probable distance of dispersion, suggests an increase in the possibility of establishing new links with other patches too. This increase in the contribution to connectivity of both components does not occur in the same way in both landscapes. In particular, in the protected landscape there is a greater importance of the $d P C f l u x$ component, so it means that individuals can reach other patches directly without the need to use intermediate stepping-stone patches. On the other hand, in the livestock landscape, the greatest contribution of the
dPCconnector component implies that individuals need to use intermediate fragments as connecting elements (stepping-stones) to reach more distant habitat patches. For this reason, the configuration of the landscape as a consequence of extensive cattle raising causes that $A$. s. Pederseni takes different characteristics as a disperser, behaving as an intermediate mobility species in Mburcuyá National Park and as a limited dispersive capacity species within the livestock landscape as a consequence of landscape degradation (Fisher and Lindenmayer 2007; Saura and Rubio 2010).

Critical elements for connectivity and management implications

For species conservation, particularly those threatened by habitat loss due to changes in natural coverage, it is extremely important to identify suitable habitat fragments and consider their connectivity within the landscape in order to maintain their populations for a long term. In addition, it is necessary to develop strategies to improve reachable habitat in order to favour the movement of individuals and gene flow among patches (Crooks and Sanjayan 2006). Functional analysis is the key concept that quantitatively calculates the importance of each patch habitat within each landscape. As other authors point out, the results of these analyzes allow the design and evaluation of conservation strategies (Decout et al. 2012; Clauzel et al. 2015). In this sense, the key patches for connectivity that were identified in the protected landscape resulted in both forest and water body edge habitats in similar proportions in terms of number of patches, but with a marked difference in area in favour of the forest habitat. On the other hand, rangeland landscape presented differences in the number of key fragments, as well as in the area of the two types of habitats. The importance of temporary habitats for maintaining landscape connectivity stands out. However, the role of the few key forest fragments becomes more relevant because they are habitats used by adults and they are present throughout the year. For this reason, it would be necessary to improve connectivity in rangeland landscapes implementing conservation strategies for these fragments and plans for habitat restoration in that landscape (Zemanova et al. 2017). From a perspective based on socio-ecological resilience, the restoration and conservation of degraded 
environments in agro-productive landscapes should be promoted (Ghazoul and Chazdon 2017). In our work, we found that both the amount of forest fragments and their density are similar between both landscapes, although with a substantial difference with respect to the covered area. For this reason, we consider necessary restoration actions like tree planting in order to reinforce the natural regeneration and expansion processes of forest fragments (Chazdon 2003).

Finally, the analysis of connectivity together with the identification of corridors allowed the identification of three critical areas that could be functioning as dispersal barriers. In these cases, the implementation of specific wildlife crossing structures for amphibians such as sewers and tunnels that allow crossing the PR87 would reduce the risk of roadkill as well as predation or dehydration because of the impacts of crossing open areas (Woltz et al. 2008; Gurrutxaga and Saura 2013). According to Aichi strategic goal C for biodiversity (CBD 2010), the improvement of connectivity, it is necessary in order to safeguard ecosystems, species and genetic diversity. In our work, we could identify the key elements of the landscape along with possible areas to improve the efficiency of biological corridors. This type of landscape interventions ensures permeability, a conservation strategy complementary to the creation of new protected areas to ensure a well-connected system of protected areas with a surrounding rangeland (CBD 2010).

Acknowledgements This work was financially supported by CONICET (Consejo Nacional de Investigaciones Científicas y Técnicas, Argentina) and the European Union project CLARISLPB (Europe-South America Network for Climate Change Assessment and Impact Studies in La Plata Basin). We acknowledge the U.S. Geological Survey (USGS, https:// earthexplorer.usgs.gov/) for facilitating satellite images through its EarthExplorer portal. To the teaching mobility program of the Ministerio de Educación for financing my training stay at the Universidad Politécnica de Madrid. Diego Aquino for his help with image classifications. To the International Union for Conservation of Nature that, through the Red List of Threatened Species (IUCN, https://www.iucnredlist.org/), freely provides bibliographic information and the spatial distribution of thousands of species. We also thank the anonymous reviewers of the draft version of the manuscript for their constructive criticism.

\section{References}

Adriaensen F, Chardon JP, De Blust G, Swinnen E, Villalba S, Gulinck H, Matthysen E (2003) The application of 'leastcost' modelling as a functional landscape model. Landsc Urban Plann 64(4):233-247

Alex Smith M, Green DM (2005) Dispersal and the metapopulation paradigm in amphibian ecology and conservation: are all amphibian populations metapopulations? Ecography $28(1): 110-128$

Álvarez B, Aguirre R, Céspedez J, Hernando A, Tedesco M (2002) Anfibios y reptiles del sistema Iberá. Comunicaciones Científicas y Tecnológicas, UNNE, Corrientes

APN (2002) Plan de manejo del Parque Nacional Mburucuyá. Administración de Parques Nacionales, Delegación Técnica Regional Nordeste Argentino. 189 pp. https://sib.gob. ar/archivos/PLAN_DE_MANEJO_Mburucuya.pdf. Accessed 05 Jan 2017

Arbo MM (2004) Flórula del Parque Nacional Mburucuyá. Temas de la Biodiversidad del Litoral Fluvial Argentino, Insugeo, Miscelánea 12:117-124

Becker CG, Fonseca CR, Haddad CFB, Batista RF, Prado PI (2007) Habitat split and the global decline of amphibians. Science 318(5857):1775-1777

Begon M, Harper JL, Townsend CR (1999) Ecología: individuos, poblaciones y comunidades. In: Omega (ed), Barcelona. pp 1148

Blaustein AR, Wake DB (1990) Declining amphibian populations: a global phenomenon? Trends Ecol Evol 5(7):203-204

Bodin Ö, Saura S (2010) Ranking individual habitat patches as connectivity providers: integrating network analysis and patch removal experiments. Ecol Modell 221(19):2393-2405

Boitani L, Falcucci A, Maiorano L, Rondinini C (2007) Ecological networks as conceptual frameworks or operational tools in conservation. Conserv Biol 21(6):1414-1422

Brea M, Zucol A (2011) The Paraná-Paraguay Basin: geology and Paleoenvironments. Hist Biogeogr Neotrop Freshw Fish 1:69-87

Cajade R, Hermida G, Piñeiro JM, Regueira E, Alcalde L, Fusco LS, Marangoni F (2017) Multiple anti-predator mechanisms in the red-spotted Argentina Frog (Amphibia: Hylidae). J Zool 302(2):94-107

Cajade R, Marangoni F, Gangenova E (2013) Age, body size and growth pattern of Argenteohyla siemersi pederseni (Anura: Hylidae) in northeastern Argentina. J Nat Hist 47(3-4):237-251

Cajade R, Schaefer EF, Duré MI, Kehr AI, Marangoni F (2010) Reproductive biology of Argenteohyla siemersi pederseni Williams and Bosso, (Anura: Hylidae) in northeastern Argentina. J Nat Hist 44(31-32):1953-1978

CBD (2010) Strategic plan for biodiversity 2011-2020 and the Aichi targets. In Report of the tenth meeting of the conference of the parties to the convention on biological diversity (COP10). https://www.cbd.int/doc/strategicplan/2011-2020/Aichi-Targets-EN.pdf. Accessed 10 Mar 2019

Céspedez JA (2000) Historia natural de la rana de Pedersen Argenteohyla siemersi pederseni (Anura: Hylidae), y 
descripción de su larva. Boletin de la Asociación Herpetologica Española 11(2):75-80

Chapin FS III, Zavaleta ES, Eviner VT, Naylor RL, Vitousek PM, Reynolds HL, Hooper DU, Lavorel S, Sala OE, Hobbie SE, Mack MC, Díaz S (2000) Consequences of changing biodiversity. Nature 405(6783):234-242

Chazdon RL (2003) Tropical forest recovery: legacies of human impact and natural disturbances. Perspect Plant Ecol Evol Syst 6(1-2):51-71

Clauzel C, Bannwarth C, Foltete JC (2015) Integrating regionalscale connectivity in habitat restoration: an application for amphibian conservation in eastern France. J Nat Conserv 23:98-107

Contreras FI (2011) Evolución de las lagunas en función de la pendiente, Lomada Norte. Provincia Corrientes, Argentina. Terra Nueva Etapa 27(42):145-163

Corn PS, Fogleman JC (1984) Extinction of montane populations of the Northern Leopard Frog (Rana pipiens) in Colorado. J Herpetol 18(2):147-152

Crooks KR, Sanjayan M (2006) Connectivity conservation: maintaining connections for nature. In: Crooks KR, Sanjayan M (eds) Connectivity conservation. Cambridge University Press, Cambridge, p 693

Cushman SA (2006) Effects of habitat loss and fragmentation on amphibians: a review and prospectus. Biol Conserv 128(2):231-240

Decout S, Manel S, Miaud C, Luque S (2012) Integrative approach for landscape-based graph connectivity analysis: a case study with the common frog (Rana temporaria) in human-dominated landscapes. Landsc Ecol 27(2):267-279

Diminich MC, Zaracho VH (2008) Argenteohyla siemersi pederseni. Reproduction. Natural History Note. Herpetol Rev 39:74-75

ESRI (2011) Release 10. Documentation Manual. Redlands, CA, Environmental Systems Research Institute. ESRI Press, California, USA

Fahrig L (2007) Non-optimal animal movement in human-altered landscapes. Funct Ecol 21(6):1003-1015

Fahrig L, Pedlar JH, Pope SE, Taylor PD, Wegner JF (1995) Effect of road traffic on amphibian density. Biol Conserv 73(3): 177-182

Fischer J, Lindenmayer DB (2007) Landscape modification and habitat fragmentation: a synthesis. Glob Ecol Biogeogr $16(3): 265-280$

Forclaz HL (2001) Uso económico del espacio y los recursos naturales. Reunión de Comunicaciones Científicas y Técnológicas, Universidad Nacional del Nordeste, Resistencia, Chaco, Argentina, octubre de 2000. https:// www.revistacyt.unne.edu.ar/unnevieja/Web/cyt/cyt/2001/ 5-Agrarias/A-008.pdf. Accessed 26 July 2017

Forman RT (1995) Land mosaics: the ecology of landscapes and regions. Cambridge University Press, Cambridge, p 632

Forman RT, Alexander LE (1998) Roads and their major ecological effects. Annu Rev Ecol Syst 29(1):207-231

Fraterrigo JM, Pearson SM, Turner MG (2009) Joint effects of habitat configuration and temporal stochasticity on population dynamics. Landsc Ecol 24(7):863-877

Gardner RC, Barchiesi S, Beltrame C, Finlayson C, Galewski T, Harrison I, Paganini M, Perennou C, Pritchard D, Rosenqvist A, Walpole M (2015) State of the world's wetlands and their services to people: a compilation of recent analyses. Available at: https://www.ramsar.org/sites/ default/files/documents/library/bn7e_0.pdf. Accessed 14 Aug 2018

Ghazoul J, Chazdon R (2017) Degradation and recovery in changing forest landscapes: a multiscale conceptual framework. Annu Rev Environ Resour 42:161-188

Grosse WR, Nöllert A (1993) The aquatic habitat of the European tree frog, Hyla arborea. In: Stumpel AHP, Tester U (eds) Ecology and conservation of the European tree frog. Institute for Forestry and Nature Research, Wageningen, pp 37-46

Gurrutxaga M, Saura S (2013) Prioritizing highway defragmentation locations for restoring landscape connectivity. Environ Conserv 41(2): 157-164

Hanski I (2005) Landscape fragmentation, biodiversity loss and the societal response. EMBO Rep 6(5):388-392

Hanski I, Gilpin M (1991) Metapopulation dynamics: brief history and conceptual domain. Biol J Linn Soc 42(1-2):3-16

IUCN (2019) The IUCN Red List of Threatened Species. Version 2019-2. https://www.iucnredlist.org. Accessed 24 July 2019

Joly P, Miaud C, Lehmann A, Grolet O (2001) Habitat matrix effects on pond occupancy in newts. Conserv Biol 15(1):239-248

Joly P, Morand C, Cohas A (2003) Habitat fragmentation and amphibian conservation: building a tool for assessing landscape matrix connectivity. CR Biol 326:132-139

Kerr JT, Deguise I (2004) Habitat loss and the limits to endangered species recovery. Ecol Lett 7(12):1163-1169

Kindlmann P, Burel F (2008) Connectivity measures: a review. Landsc Ecol 23(8):879-890

Lambin EF, Turner BL, Geist HJ, Agbola SB, Angelsen A, Bruce JW, Coomes OT, Dirzo R, Fischer G, Folke G, George PS, Homewood K, Imbernon J, Leemans R, Li X, Moran EF, Mortimore M, Ramakrishnan PS, Richards JF, Skanes H, Steffen W, Stone GD, Svedin U, Veldkamp TA, Vogel C, Xu J (2001) The causes of land-use and landcover change: moving beyond the myths. Glob Environ Change 11(4):261-269

Lang S, Tiede D (2003) vLATE Extension für ArcGIS - vektorbasiertes Tool zur quantitativen Landschaftsstrukturanalyse [vLATE extension for ArcGIS - vector based tool for quantitative analyses of landscape structure], Salzburg. https://sites.google.com/site/largvlate/gis-tools/v-late. Accessed 3 Oct 2017

Lavilla E, Céspedez J, Baldo D, Blotto B, Langone J (2004) Argenteohyla siemersi. IUCN Red List Threat Species 2004:e.T55302A11285912

Mazerolle MJ, Desrochers A (2005) Landscape resistance to frog movements. Can J Zool 83(3):455-464

McGarigal K, Marks BJ (1995) FRAGSTATS: spatial pattern analysis program for quantifying landscape structure. Department of Agriculture, Forest Service Pacific Northwest Research Station, Portland, Portland

McRae BH, Kavanagh DM (2011) Linkage mapper connectivity analysis software. The Nature Conservancy, Seattle

Meza-Torres EI, de la Sota ER, Ferrucci MS (2013) Biogeographic analysis and key to the genera of ferns and lycophytes of Mburucuyá National Park, Corrientes, Argentina. Revista Chilena de Historial Natural 86:49-61 
Middleton RG (2010) Cattle access affects periphyton community structure in Tennessee farm ponds. Master's Thesis, University of Tennessee, Knoxville. 89 pp. https:// trace.tennessee.edu/utk_gradthes/732. Accessed 9 April 2019

Minor ES, Urban DL (2008) A graph-theory framework for evaluating landscape connectivity and conservation planning. Conserv Biol 22(2):297-307

Mühlner S, Kormann U, Schmidt-Entling M, Herzog F, Bailey D (2010) Structural versus functional habitat connectivity measures to explain bird diversity in fragmented orchards. J Landsc Ecol 3(1):52-64

Opdam P, van Apeldoorn R, Schotman A, Kalkhoven J (1993) Population responses to landscape fragmentation. Chap. 7 pp. In: Vos CC, Opdam P (eds) Landscape ecology of a stressed environment. Springer, Dordrecht, pp 147-171

Piñeiro JM, Cajade R, Courtis A, Ingaramo MdR, Marangoni F (2019) Chronology of the LAGs formation and body growth in Argenteohyla siemersi from northeastern Argentina. North-Western J Zool 2019:e182502

Pollo FE, Martina LC, Bionda CL, Salas NE, Martino AL (2015) Trophic ecology of syntopic anuran larvae, Rhinella arenarum (Anura: Bufonidae) and Hypsiboas cordobae (Anura: Hylidae): its relation to the structure of periphyton. Annales de Limnologie-Int J Limnol 51(3):211-217

Popolizio E (1996) Las unidades geomorfológicas del NEA. En Actas del Congreso Nacional de Geografia. Sociedad Argentina de Estudios Geográficos pp 15

Ray N, Lehmann A, Joly P (2002) Modeling spatial distribution of amphibian populations: a GIS approach based on habitat matrix permeability. Biodivers Conserv 11(12):2143-2165

Rubio L, Rodríguez-Freire M, Mateo-Sánchez MC, Estreguil C, Saura S (2012) Sustaining forest landscape connectivity under different land cover change scenarios. For Syst 21(2):223-235

Rustigian HL, Santelmann MV, Schumaker NH (2007) Amphibian population dynamics. In: Nassauer JI, Santelmann MV, Scavia D (eds) From the Corn Belt to the Gulf: Societal and environmental implications of alternative agricultural Futures. RFF Press, Washington, DC, pp 108-114

Sahuquillo M, Miracle MR, Morata SM, Vicente E (2012) Nutrient dynamics in water and sediment of Mediterranean ponds across a wide hydroperiod gradient. Limnol-Ecol Manag Inland Waters 42(4):282-290

Saibene CS, Montanelli SB (1997) Mapeo de las comunidades vegetales leñosas del Parque Nacional Mburucuyá, Corrientes, Argentina. Facena 13:49-57

Sala OE, Chapin FS, Armesto JJ, Berlow E, Bloomfield J, Dirzo R, Huber-Sanwald E, Huenneke LF, Jackson RB, Kinzig A, Leemans R, Lodge DM, Mooney HA, Oesterheld M, LeRoy Poff N, Sykes MT, Walker BH, Walker M, Wall DH (2000) Global biodiversity scenarios for the year 2100 . Science 287(5459):1770-1774
Saura S, Estreguil C, Mouton C, Rodríguez-Freire M (2011) Network analysis to assess landscape connectivity trends: application to European forests (1990-2000). Ecol Indic 11(2):407-416

Saura S, Pascual-Hortal L (2007) A new habitat availability index to integrate connectivity in landscape conservation planning: comparison with existing indices and application to a case study. Landsc Urban Plann 83(2-3):91-103

Saura S, Rubio L (2010) A common currency for the different ways in which patches and links can contribute to habitat availability and connectivity in the landscape. Ecography 33(3):523-537

Saura S, Torné J (2009) Conefor Sensinode 2.2: a software package for quantifying the importance of habitat patches for landscape connectivity. Environ Modell Softw 24(1):135-139

Schivo F (2015) Modelos de respuestas de anfibios frente a cambios ambientales en humedales de Corrientes (Doctoral dissertation). Universidad de Buenos Aires, Argentina. 210 pp. https://bibliotecadigital.exactas.uba.ar/ download/tesis/tesis_n5688_Schivo.pdf. Accessed 18 June 2018

Stebbins RC, Cohen NW (1995) A natural history of amphibians. Princeton University Press, Princeton, p 316

Taylor PD, Fahrig L, Henein K, Merriam G (1993) Connectivity is a vital element of landscape structure. Oikos 68:571-573

Urban D, Keitt T (2001) Landscape connectivity: a graph-theoretic perspective. Ecology 82(5):1205-1218

Wiens JA (2001) The landscape context of dispersal. In: Clobert J, Danchin E, Dhondt AA, Nichols JD (eds) Dispersal. Oxford University Press, New York, p 480

Wiens JA, Chr N, Van Horne B, Ims RA (1993) Ecological mechanisms and landscape ecology. Oikos 66:369-380

Williams JD, Bosso A (1994) Estado sistemático y distribución geográfica de Argenteohyla siemersi (Mertens, 1937) en la República Argentina (Anura: Hylidae). Cuadernos de Herpetologia 8:57-62

With KA (1997) The application of neutral landscape models in conservation biology. Conserv Biol 11(5):1069-1080

Woltz HW, Gibbs JP, Ducey PK (2008) Road crossing structures for amphibians and reptiles: informing design through behavioural analysis. Biol Conserv 141(11):2745-2750

Zaracho VH, Areta JI (2008) The advertisement call of Argenteohyla siemersi pederseni (Amphibia, Anura, Hylidae) and comments on its taxonomic status. FACENA 24:49-57

Zemanova MA, Perotto-Baldivieso HL, Dickins EL, Gill AB, Leonard JP, Wester DB (2017) Impact of deforestation on habitat connectivity thresholds for large carnivores in tropical forests. Ecol Process 6(1):21

Publisher's Note Springer Nature remains neutral with regard to jurisdictional claims in published maps and institutional affiliations. 